\title{
THE ROLE OF MAGENTIC IRON AND SODIUM SELENATE IN MINIMIZING SOIL SALT HAZARDS ON GROWTH AND QUALITY OF JACARANDA ACUTIFOLIA HUMB. \& BONPL. SEEDLINGS
}

\author{
Gehan H. Abdel-Fattah \\ Botanical Gardens Res. Dept., Hort. Res. Inst., ARC, Giza, Egypt.

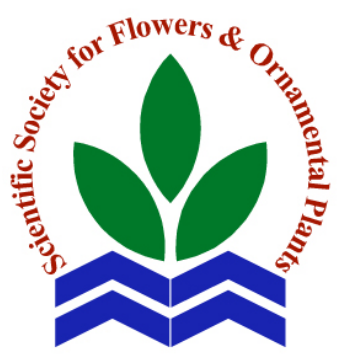 \\ Scientific J. Flowers \& \\ Ornamental Plants, \\ 1(3):187-198 (2014). \\ Received: \\ $22 / 10 / 2014$ \\ Revised by: \\ Prof. Dr. E.S. Nofal, \\ Kafr El-Sheikh Univ. \\ Prof. Dr. S.M. Shahin, \\ Hort. Res. Inst., ARC.

\begin{abstract}
The purpose of this study is exploring the role of some chemicals, namely magnetic iron $\left(\mathrm{Fe}_{3} \mathrm{O}_{4}\right)$ and sodium selenate $\left(\mathrm{Na}_{2} \mathrm{SeO}_{4}\right)$ on avoiding or minimizing soil salt hazards on growth and quality of Jacaranda acutifolia Humb. \& Bonpl. seedlings. Thus, a pot experiment was conducted under the full sun at the nursery of Hort. Res. Inst., ARC, Giza, Egypt during 2011 and 2012 seasons, where one-year-old seedlings of Jacaranda were planted in $30 \mathrm{~cm}$ diameter plastic pots filled with about $7 \mathrm{~kg}$ of sand and clay mixture (1:1, v:v) salinized with an equal mixture of $\mathrm{NaCl}$ and $\mathrm{CaCl}_{2}$ pure salts $(1: 1, \mathrm{w}: \mathrm{w})$ at the concentrations of $0,1000,2000$ and $4000 \mathrm{ppm}$. Magnetic iron was applied three times as soil drench at the rate of $4 \mathrm{~g} / \mathrm{pot}$, while sodium selenate was added 3 times as foliar spray at $2 \mathrm{ppm}$. The effect of a combination between $\mathrm{Fe}_{3} \mathrm{O}_{4}$ at $4 \mathrm{~g} /$ pot and $\mathrm{Na}_{2} \mathrm{SeO}_{4}$ at $2 \mathrm{ppm}$ was also studied.

The obtained results revealed that means of vegetative and root growth characters were progressively decreased with increasing soil salinity level with significant differences relative to control means in the two seasons, but they were significantly increased as a result of applying magnetic iron, selenate or both in the combined treatment. The best vegetative and root growth, however was attained by planting in unsalinized soil mixture with the addition of both $\mathrm{Fe}_{3} \mathrm{O}_{4}(4 \mathrm{~g} /$ pot $)$ and $\mathrm{Na}_{2} \mathrm{SeO}_{4}(2 \mathrm{ppm})$, as this interaction treatment gave the tallest plants, the longest root, the highest number of leaves and the heaviest fresh and dry weights of aerial parts and roots compared to all other interactions in both seasons. It was also noticed that leaf content of chlorophyll $\mathrm{a}$ and $\mathrm{b}$ and percentage of nitrogen, phosphorus and potassium were gradually decreased as the soil salinity level was increased, while they were significantly increased by drenching the soil with magnetic iron or spraying the foliage with the sodium selenate solution, or by adding these two chemicals in together. The opposite was the right regarding leaf content of carotenoids, sodium $\%$, chloride $\%$ and free proline, as these constituents were progressively increased with rising salinity level, but were decreased by the two used chemicals when applied either individually or in combination. In general, applying magnetic iron alone or combining with $\mathrm{Na}-$ selenate gave better results than the sole application of Na-selenate, whereas the mastery in all previous measurements was for the interaction of planting in unsalinized soil plus application of $\mathrm{Fe}_{3} \mathrm{O}_{4}(4 \mathrm{~g} /$ pot $)+\mathrm{Na}_{2} \mathrm{SeO}_{4}(2$ ppm) that recorded the utmost high means in both seasons.

From these results, it is recommended to drench the soil mixture with 4 $\mathrm{g} /$ pot of magnetic iron, alone or plus spraying of Na-selenate $2 \mathrm{ppm}$ on the foliage to get the best growth and quality of Jacaranda acutifolia seedlings planted in either salinized or unsalinized soil.
\end{abstract}

Key words: Jacaranda acutifolia, soil salinity, magnetic iron, sodium selenate, vegetative and root growth, chemical composition and active constituents. 


\section{INTRODUCTION}

Jacaranda acutifolia Humb. \& Bonpl. (Fam. Bignoniaceae) is a delicate deciduous, medium-sized tree up to $15 \mathrm{~m}$ height or more with its bipinnate, fern-like leaves giving it a feathery appearance. Flowers are blue, in large, loose, pyramidal clusters appearing in March when the tree is leafless and lasting till after the development of new leaves, at this time, the bell-shaped, 2-lipped flowers amongst the feathery crown gives the tree a very attractive appearance. It is widely used in tropics and subtropics as flowering and shading tree. Propagated by seeds and cuttings (El-Hadidi and Boulos, 1979).

Soil salinity is still a major abiotic stress factor reducing growth, flowering and yield of many varieties of plants all over the world (Tester and Davenport, 2003). Overcoming the negative effects of salinity using magnetite (magnetic iron) becomes one of the most important ways applied recently. In this concern, El-Hifny et al. (2008) indicated that increasing magnetite level up to 200 $\mathrm{kg} /$ fed led to an increase in all vegetative growth characters, curd weight, yield and content of $\mathrm{N}, \mathrm{P}, \mathrm{K}$ and $\mathrm{Fe}$ in leaves and curds of cauliflower, but decreased $\mathrm{Na}$ and $\mathrm{Cl}$ content in the leaves and curds. Similary, were those results pointed out by Ali et al. (2011) on pepper, Ahmed et al. (2011) on Hibiscus sabdariffa, Shehata et al. (2012) on cucumber, Ali et al. (2013) on grapevines, Abdel-All and Mohammed (2014) on broccoli and cauliflower and El-Sayed (2014) who found that magnetic water enhanced growth, yield and water content of broad bean plants, as well as chlorophyll a and b, carotenoids, total carbohydrates, protein, total amino acids, proline, total indoles, total phenols, $\mathrm{GA}_{3}$, RNA, DNA, P, $\mathrm{K}, \mathrm{Na}$ and $\mathrm{Ca}$ in all parts of the plant under greenhouse conditions.

In addition, selenium can regulate the water status of plants under salinity or drought conditions. It can also increase the tolerance of plants to UV-induced oxidative stress, delay senescence and promote the growth of ageing seedlings (Germ and Stibilj, 2007). On maize, Hawrylak-Nowak (2008) reported that $\mathrm{P}$ and $\mathrm{Ca}$ content increased, while $\mathrm{K}$ content decreased with increasing Se treatments. At low level, selenium tended to stimulate the plant growth and root elongation, but at higher one, the dry mass accumulation and root tolerance index were severly decreased. Similar observations were also obtained by Euliss and Carmichael (2004) on canola, Kaklewski et al. (2008) on wheat and rape, Lyons et al. (2009) on Brassica rapa, Lehotai et al. (2011) on Arabidopsis thaliana, Hajiboland and Keivanfar (2012) on canola and Saffaryazdi et al. (2012) who noticed that shoot and root length, shoot and root fresh and dry weights and total dry weight of spinach plants were increased in response to the lowest concentration of Se (1 ppm), while higher concentrations (6 and 10 ppm) reduced these parameters. The low concentration enhanced also contents of chlorophylls $\mathrm{a}$ and $\mathrm{b}$, while higher levels exert toxic effects. Total phenols in leaves were linearly increased with increasing Se level to reach the maximum by $10 \mathrm{ppm} \mathrm{Se}$, $\mathrm{Na}$ and $\mathrm{Ca}$ contents were increased, while $\mathrm{K}$ content was decreased by increasing $\mathrm{Se}$ level.

The aim of this work was to detect the suitable treatments for alleviating the deleterious effects of soil salinity on growth and quality of the salt-sensitive Jacaranda seedlings of one year old.

\section{MATERIALS AND METHODS}

In order to raise tolerance of Jacaranda seedlings to salinity stress, the current study was performed under the open field at the nursery of Hort. Res. Inst., ARC, Giza, Egypt during the two successive seasons of 2011 and 2012, where one-year-old uniform seedlings of Jacaranda acutifolia Humb. \& Bonpl. at a height of about $30 \mathrm{~cm}, 4.7 \mathrm{~mm}$ stem diameter and 4-5 leaves were planted on mid of February for each season in 30 $\mathrm{cm}$-diameter plastic pots (one seedling/pot) filled with about $7 \mathrm{~kg} /$ pot of an equal 
mixture of sand and clay by volume. Some physical and chemical properties of the sand and clay used in the two seasons were determined and illustrated in Table (1).

\section{The experimental treatments were:}

\section{1- Salinization treatments:}

Immediately before planting, the soil mixture was salinized with a salt mixture of pure $\mathrm{NaCl}$ and pure $\mathrm{CaCl}_{2}(1: 1$, by weight) at the concentrations of $0,1000,2000$ and 4000 ppm.

\section{2- Chemical substances:}

Magnetite (magnetic iron, $\mathrm{Fe}_{3} \mathrm{O}_{4}$ ) was applied as soil drench at the rate of $4 \mathrm{~g} /$ pot, 3 times; the first batch was added immediately before planting and the other two after 45 days later from the batch previous it.

Sodium selenate $\left(\mathrm{Na}_{2} \mathrm{SeO}_{4}\right)$ was added as a thorough foliar spray at the rate of 2 ppm, 3 times. The $1^{\text {st }}$ spray was done 45 days after planting (on April, $1^{\text {st }}$ ) and the other two at one month interval (on first of May and first of June, respectively).

A combination of magnetite $(4 \mathrm{~g} / \mathrm{pot})$ and sodium selenate ( $2 \mathrm{ppm}$ ) was employed at the same times of application mentioned above for each chemical substance.

\section{3- Interaction treatments:}

The treatments of both salinization and chemicals were combined factorially to form sixteen interactions.

The seedlings of all treatments were fertilized 3 times throughout the course of this study with $5 \mathrm{~g} /$ pot of NPK chemical fertilizer (1:1:1) starting from mid March at one month interval and watered every other day. The other agricultural practices were carried out whenever needed.
A randomized block design with factorial concept, replicated thrice with 5 seedlings per replicate (Das and Giri, 1986) was used in the two seasons. At the end of each season (on September, $30^{\text {th }}$ ), data were recorded as follows: plant height $(\mathrm{cm})$, stem diameter at the base $(\mathrm{cm})$, number of leaves/plant, leaf length and width $(\mathrm{cm})$, root length $(\mathrm{cm})$ and aerial parts and roots fresh and dry weights $(\mathrm{g})$. In fresh leaf samples, the photosynthetic pigments (chlorophyll a, b and carotenoids, $\mathrm{mg} / \mathrm{g} \mathrm{f.w.)}$ and free proline (mg/g f.w.) were determined using the methods of Saric et al. (1976) and Bates et al. (1973), respectively, while in dry leaf ones, the percentages of nitrogen (using micro-Kjeldahle method described by Pregl, 1945), phosphorus (Luatanab and Olsen, 1965), sodium (using Flame-photometer set) and chloride (Jackson, 1973) were measured.

Data were then tabulated and subjected to analysis of variance following SAS Institute Program (1994) with Duncan's Multiple Range Test (Duncan, 1955) for means comparison.

\section{RESULTS AND DISCUSSION}

Effect of soil salinity, magnetic iron, sodium selenate and their interactions on:

1-Vegetative and root growth parameters:

It is evident from data shown in Tables (2, 3, 4 and 5) that means of all vegetative and root growth traits were progressively decreased with increasing salinity level compared to those of control treatment in the two seasons. Hence, the least averages were recorded by the highest salinity rate ( 4000 ppm). The opposite was the right regarding the effect of magnetic iron, Na-selenate or both in combination, as these chemicals

Table 1. Physical and chemical properties of the used sand and clay during 2011 and 2012 seasons.

\begin{tabular}{|c|c|c|c|c|c|c|c|c|c|c|c|c|c|c|c|}
\hline \multirow{2}{*}{$\begin{array}{c}\text { Soil } \\
\text { texture }\end{array}$} & \multirow{2}{*}{ Season } & \multicolumn{4}{|c|}{$\begin{array}{c}\text { Particle size } \\
\text { distribution(\%) }\end{array}$} & \multirow{2}{*}{ S.P. } & \multirow{2}{*}{$\begin{array}{c}\text { E.C } \\
(\mathrm{ds} / \mathrm{m})\end{array}$} & \multirow{2}{*}{ pH } & \multicolumn{4}{|c|}{ Cations (meq/l) } & \multicolumn{3}{|c|}{ Anions (meq/l) } \\
\hline & & $\begin{array}{c}\text { Coarse } \\
\text { sand }\end{array}$ & $\begin{array}{l}\text { Fine } \\
\text { sand }\end{array}$ & Silt & Clay & & & & $\mathrm{Ca}^{++}$ & $\mathbf{M g}^{++}$ & $\mathbf{N a}^{+}$ & $\mathbf{K}^{+}$ & $\mathrm{HCO}_{3}^{-}$ & $\mathrm{Cl}^{-}$ & $\mathrm{SO}_{4}^{--}$ \\
\hline \multirow{2}{*}{ Sand } & 2011 & 81.53 & 9.55 & 0.42 & 8.50 & 22.88 & 3.50 & 7.67 & 10.50 & 1.56 & 30.60 & 0.57 & 4.50 & 23.10 & 15.63 \\
\hline & 2012 & 80.75 & 10.30 & 1.26 & 7.69 & 23.10 & 3.82 & 7.83 & 8.96 & 8.33 & 17.66 & 0.75 & 3.48 & 18.67 & 13.55 \\
\hline \multirow{2}{*}{ Clay } & 2011 & 7.54 & 22.28 & 30.55 & 39.63 & 55.00 & 2.33 & 8.30 & 7.82 & 2.12 & 15.40 & 0.75 & 6.60 & 8.20 & 11.29 \\
\hline & 2012 & 7.64 & 22.50 & 30.15 & 39.71 & 50.00 & 2.26 & 8.12 & 8.12 & 2.20 & 15.50 & 0.75 & 6.78 & 8.02 & 11.15 \\
\hline
\end{tabular}


Gehan H. Abdel-Fattah

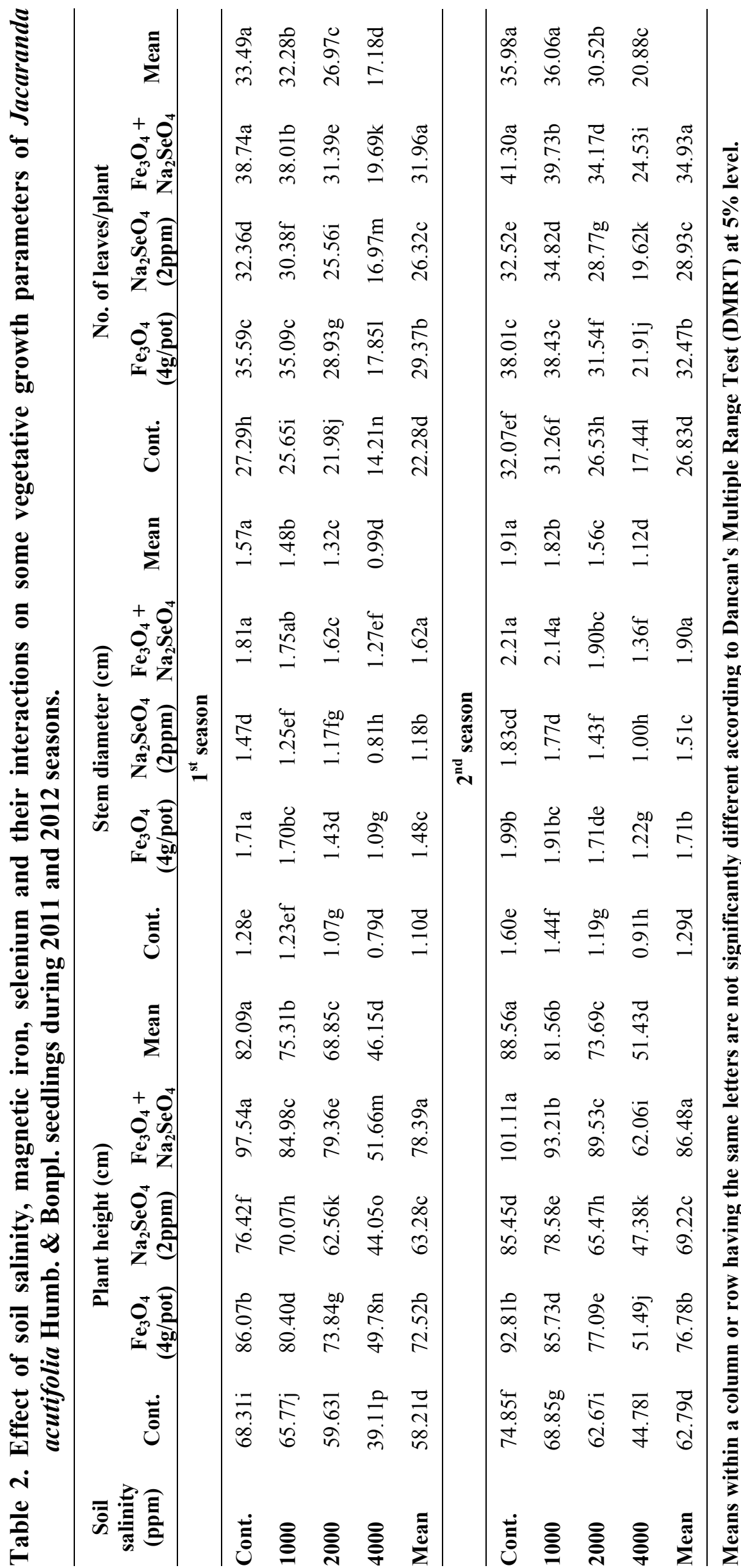




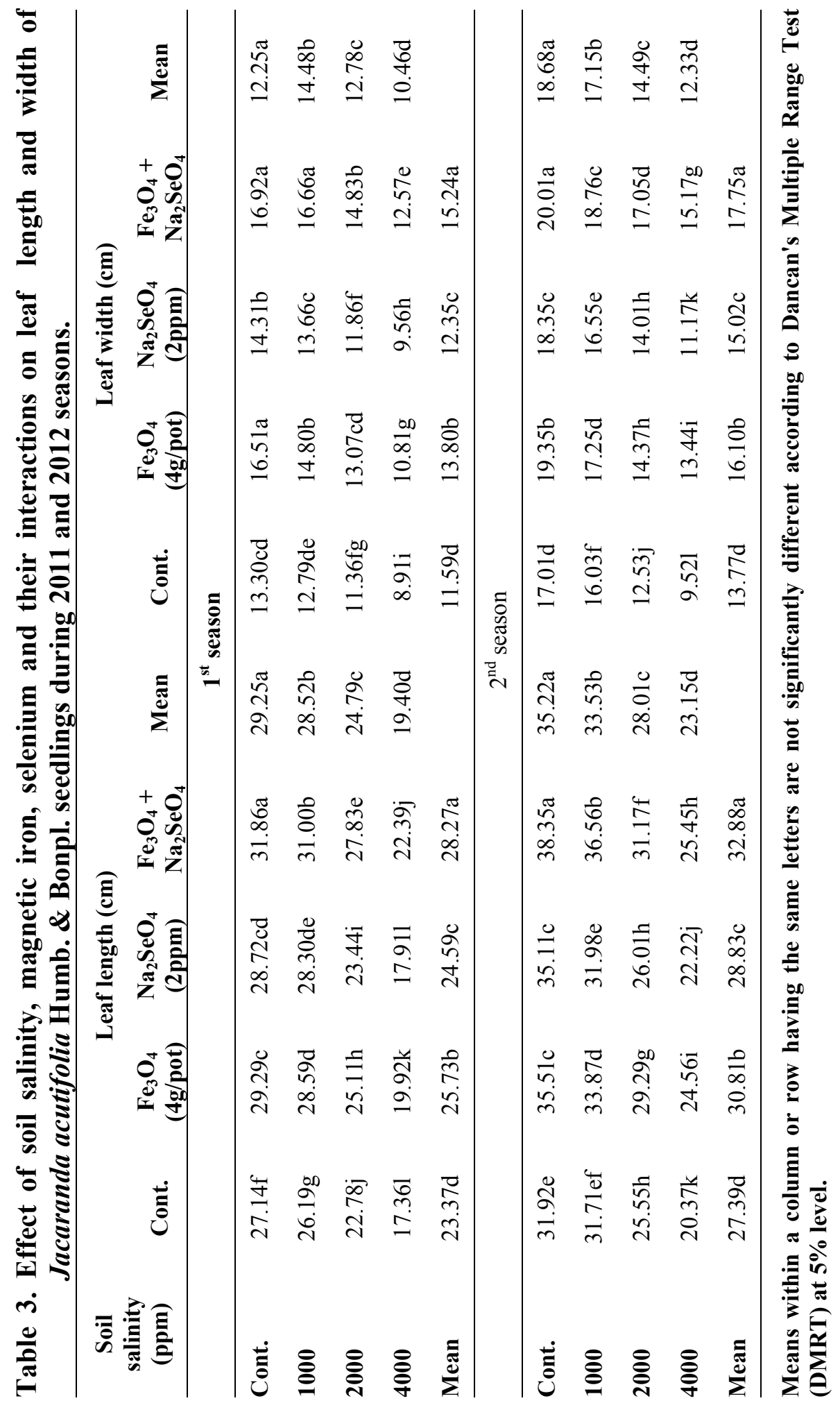




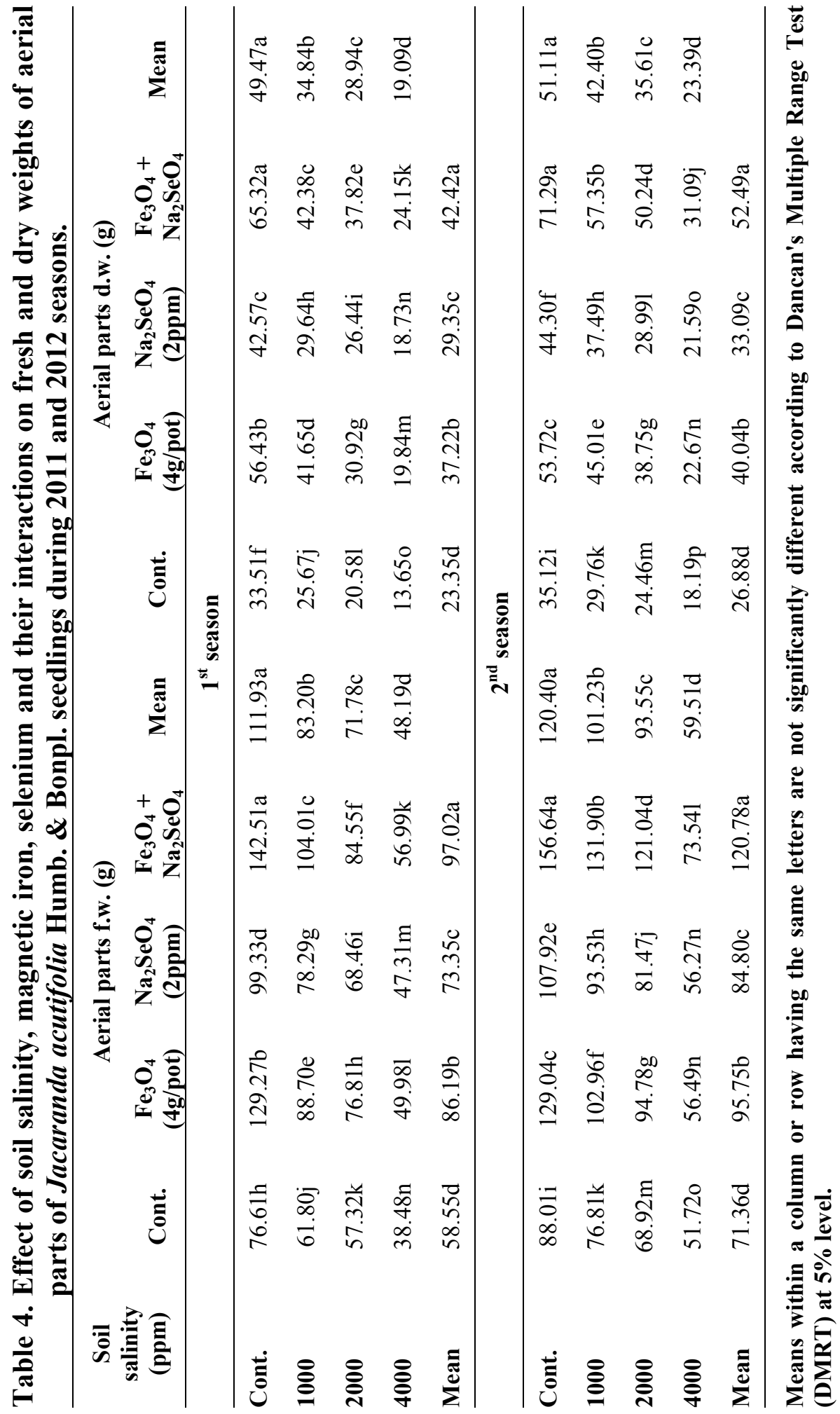




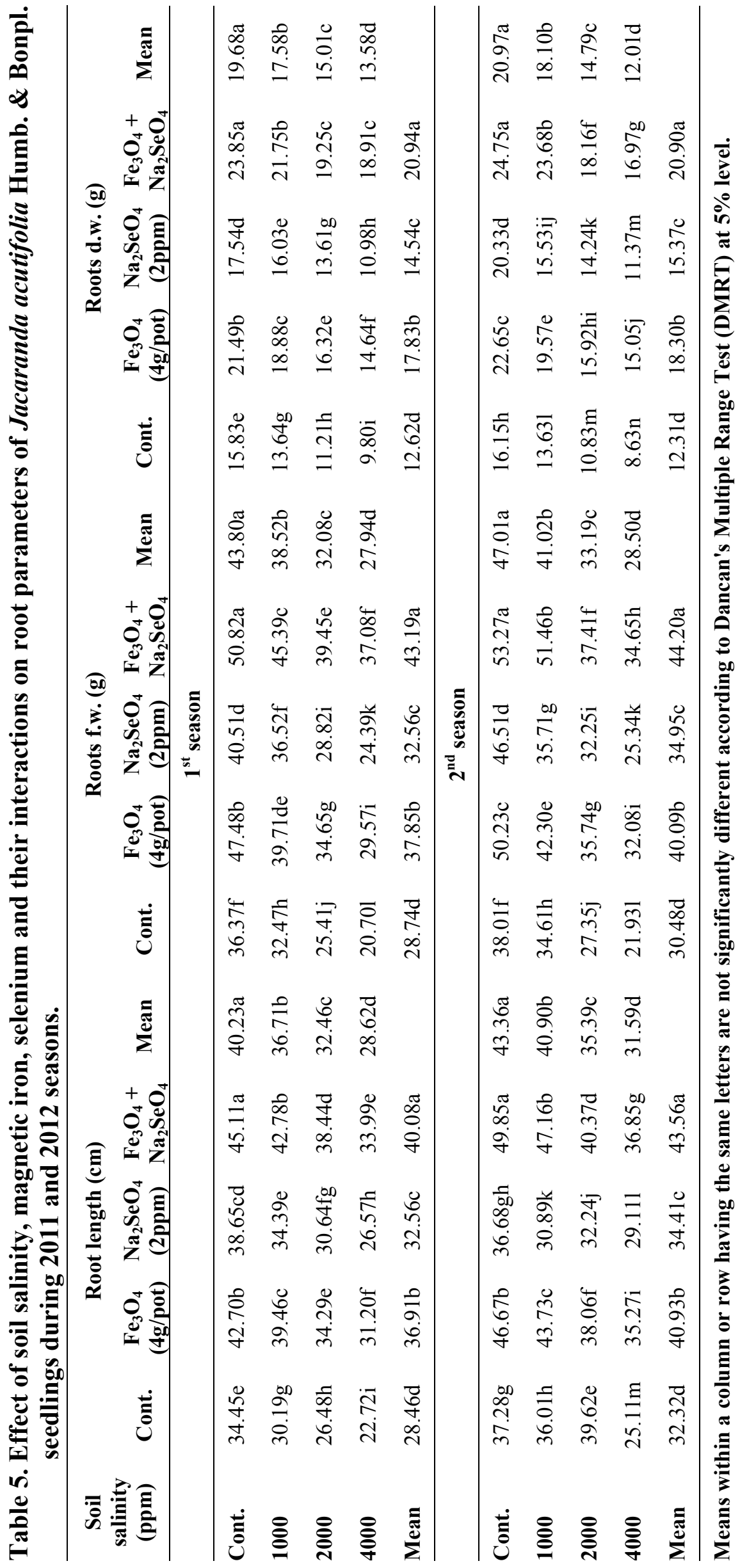


significantly improved vegetative and root growth of treated plants over untreated ones, with the superiority of the combined treatment between magnetic iron at $4 \mathrm{~g} / \mathrm{pot}$ and Na-selenate at $2 \mathrm{ppm}$ which gave the highest values in both seasons, this was followed by the sole application of $\mathrm{Fe}_{3} \mathrm{O}_{4}$ that gave means occupied the second rank in most cases of the two seasons. Generally, the best vegetative and root growth in both seasons were found due to planting in unsalinized soil mixture plus drenching with $\mathrm{Fe}_{3} \mathrm{O}_{4}$ at $4 \mathrm{~g} /$ pot and foliar spraying with $\mathrm{Na}_{2} \mathrm{SeO}_{4}$ at $2 \mathrm{ppm}$, as this interaction gave the utmost high averages over all other interactions in the two seasons. The combining between planting in the soil free from salination and drenching with magnetite alone at $4 \mathrm{~g} /$ pot came in the second position after the above mentioned super interaction.

Salinity depresses the growth of plants by affecting water absorption and biochemical processes, such as $\mathrm{N}, \mathrm{CO}_{2}$ assimilation and protein biosynthesis or accumulating high concentration of potentially toxic ions such as $\mathrm{Na}$ and $\mathrm{Cl}$ (Gunes et al., 1999). Chartzoulakis and Klapaki (2000) attributed the reduction in growth by salinity to the effect of osmotic stress and the inhibition of cell division rather than cell expansion plus the marked inhibition in photosynthesis. They added also that high salinity levels led to decrease in leaf number due to leaf abscission as a result of ion accumulation in the leaves, particularly old ones. Moreover, Jou et al. (2006) suggested that ATPase participates in endoplasmic reticulum-Golgi mediated protein sorting machinery for both house keeping function and compartmentalization of excess $\mathrm{Na}^{+}$under high salinity.

On the other side, application of either magnetic iron or selenate markedly alleviate the harmful effect of salinity resulting in rising tolerance of Jacaranda seedlings to salt stress. This may indicate the role of magnetite in enhancing of $\mathrm{N}, \mathrm{P}, \mathrm{K}$ and $\mathrm{Fe}$ uptake which stimulate plant growth against the harmful effect of $\mathrm{Na}$ and $\mathrm{Cl}$ which inhibit plant growth. It induces cell metabolism and mitosis of meristematic cells (Belyavskaya, 2001). It is believed that new protein bands are formed in plants that are treated with magnetite and these proteins are responsible for increased growth (Hozyan and AbdulQados, 2010). Besides, it decreases the hydration of salt ions and colloids, having a positive effect on salt solubility leading finally to leaching of salts. So, it is successfully used to reclaim soils with high cations and anions content, such as $\mathrm{Ca}, \mathrm{Na}$ and $\mathrm{HCO}_{3}$ (Mostafazadeh et al., 2012). As for selenate, it can increase the tolerance of plants to UV-induced oxidative stress, delay senescence, promote the growth of ageing seedlings and has the ability to regulate the water status of plants under conditions of salinity or drought (Germ and Stibilj, 2007).

The previous results were supported by those of Euliss and Carmichael (2004) on canola, El-Hifny et al. (2008) on cauliflower, Lyons et al. (2009) on Brassica rapa, Lehotai et al. (2011) on Arabidopsis thaliana, Ali et al. (2013) on grapevines, Abdel-All and Mohammed (2014) on broccoli and cauliflower.

\section{2- Chemical composition of the leaves:}

Data presented in Table (6) exhibit that chlorophyll $\mathrm{a}$ and $\mathrm{b}$ content (mg/g f.w.), as well as the percentages of nitrogen, phosphorus and potassium were gradually decreased in the leaves with increasing salinity level in the soil to reach the minimum values at the highest salinity level (4000 ppm) compared to the control means. However they were significantly increased as a result of drenching the soil with magnetic iron or spraying the foliage with $\mathrm{Na}$-selenate, with the prevalence of $\mathrm{Fe}_{3} \mathrm{O}_{4}$ alone or combined with $\mathrm{Na}_{2} \mathrm{SeO}_{4}$, as these two treatments recorded alternately the highest content. This may indicate the role of magnetite and selenate in repairing the decline in these important constituents caused by salinity. 
Scientific J. Flowers \& Ornamental Plants, 1(3):187-198 (2014)

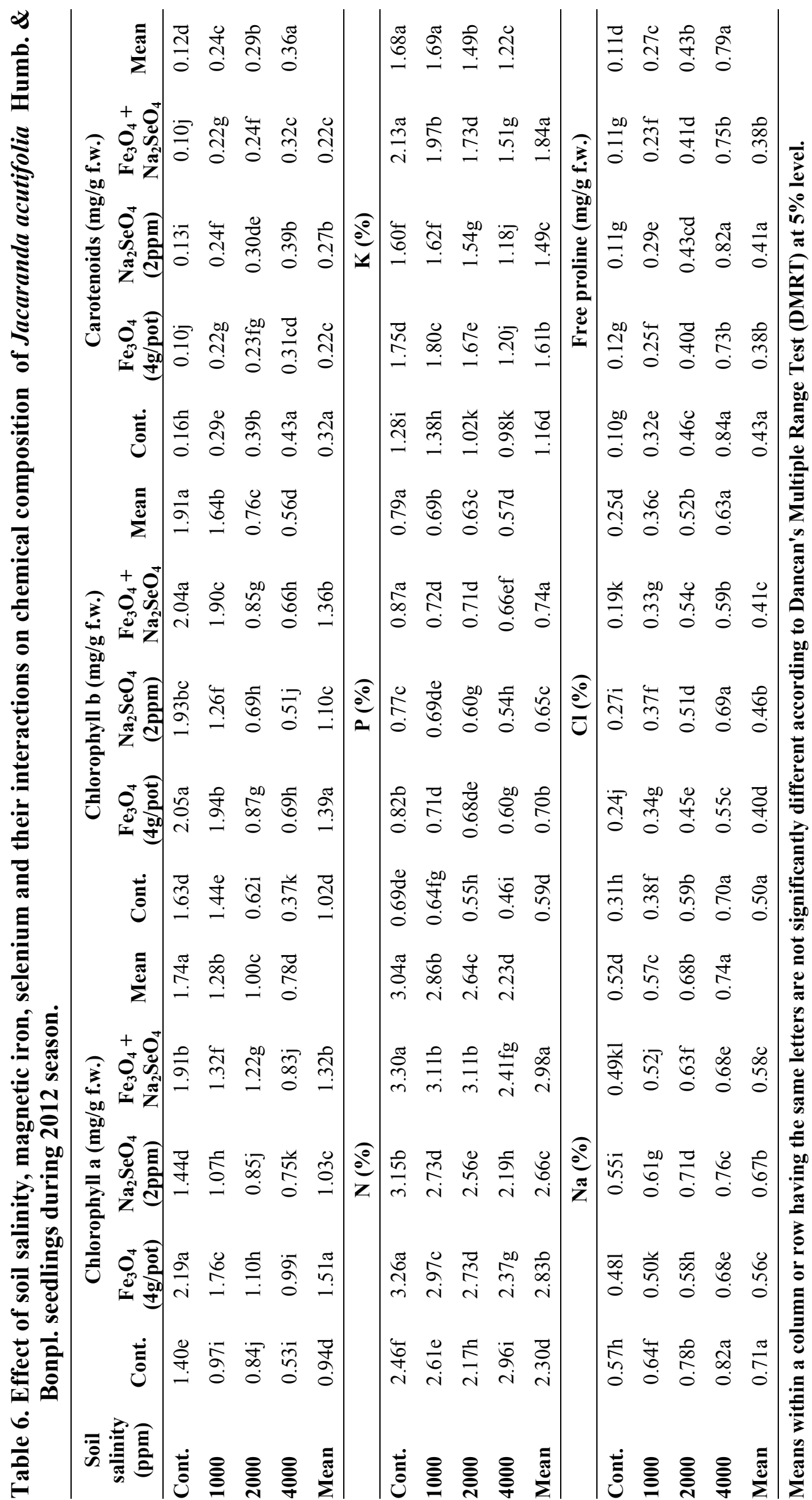


The opposite was right concerning carotenoids and free proline content $(\mathrm{mg} / \mathrm{g}$ f.w.) and the percent of sodium and chloride which progressively increased with elevating salinity level, but decreased in response to magnetic iron and selenate, applied either individually or in combination. In general, the maximum content of chlorophylls a and $\mathrm{b}$, as well as of $\mathrm{N}, \mathrm{P}$ and $\mathrm{K} \%$ was attained by planting in nonsalinized soil plus addition of $\mathrm{Fe}_{3} \mathrm{O}_{4}$ alone or with $\mathrm{SeO}_{4}$. That was true for the content of carotenoids, $\mathrm{Na}, \mathrm{Cl}$ and free proline when Jacaranda seedlings were planted in high salinized soil (4000 ppm) with the absence of either magnetic iron or Na-selenate. This means that magnetic iron and Na-selenate play a vital role in reducing the harmful effect of salinity through decreasing the absorption of $\mathrm{Na}$ and $\mathrm{Cl}$ from soil solution under high salinity conditions.

In this regard, El-Hifny et al. (2008) noted that the favourable influence of magnetite application on increasing the content of $\mathrm{N}, \mathrm{P}, \mathrm{K}$ and $\mathrm{Fe}$ with reducing that of $\mathrm{Na}$ and $\mathrm{Cl}$ may be attributed to creating a high energy magnetic field in the root media of the growing plants, and this in turn, may stimulate the absorption of these elements and decrease that of $\mathrm{Na}$ and $\mathrm{Cl}$. Furthermore, magnetate solubolises $\mathrm{NaCl}$ salt and leaches it out of the soil. Thus, the plants do not uptake higher amounts of either $\mathrm{Na}$ or $\mathrm{Cl}$.

The aforestated gains, however are in great parallel with those elicited by Germ and Stibilj (2007) on maize, Kaklewski et al. (2008) on wheat and rape, Ahmed et al. (2011) on Hibiscus sabdariffa, Shehata et al. (2012) on cucumber, Saffaryazdi et al. (2012) on spinach and El-Sayed (2014) on Vicia faba.

From the above mentioned discussion, it is advised to drench magnetic iron at the rate of $4 \mathrm{~g} / \mathrm{pot}$, alone or with spraying of $\mathrm{Na}$ selenate on the foliage at the rate of $2 \mathrm{ppm}$ for the best growth and quality of Jacaranda acutifolia seedlings cultivated either in salinized or nonsalinized soil.

\section{REFERENCES}

Abdel-All, H.M. and Mohammed, Y.A. (2014). Improved salt tolerance of broccoli and cauliflower by adding magnetic iron and seamino and reflection of this on yield and sulforaphane content under Sinai conditions. J. Appl. Sci. Res., 10(1):22-31.

Ahmed, Y.M.; Shalaby, E.A. and Shanan, Nermeen T. (2011). The use of organic and inorganic cultures in improving vegetative growth, yield characters and antioxidant activity of roselle plants (Hibiscus sabdariffa, L.). African J. BioTech., 10(11):1988-1996.

Ali, Mervat A.; El-Gendy, Rafaat, S.S. and Ahmed, Ola A. (2013). Minimizing adverse effects of salinity in vineyard. J. Hort. Sci. \& Ornam. Plants, 5(1):12-21.

Ali, T.B.; Khalil, Soha E. and Khalil, A.M. (2011). Magnetic treatments of Capsicum annuum, L. grown under saline irrigation conditions. J. Appl. Sci. Res., 7(11):1558-1568.

Bates, L.S.; Waldern, R.P. and Tear, I.D. (1973). Rapid determination of free proline under water stress studies. Plant and Soil, 39:205-207.

Belyavskaya, N.A. (2001). Ultrastructure and calcium balance in meristem cells of pea roots exposed to extremely low magnetic field. Adv. Space Res., 28:645650 .

Chartzoulakis, K. and Klapaki, K. (2000). Response of two different greenhouse pepper hybrids to $\mathrm{NaCl}$ salinity during different growth stages. Sci. Hort., $86: 247-260$.

Das, M.N. and Giri, N.C. (1986). Design and Analysis of Experiments, $2^{\text {nd }}$ Ed., published by Mohinder Singh Sejwalfor Wiley Eastern Ltd., New Delhi 110002, $488 \mathrm{pp}$.

Duncan, D.B. (1955). Multiple range and multiple F-test. J. Biometrics, 11:1-42. 
El-Hadidi, M.N. and Boulos, L. (1979). Street Trees in Egypt, $2^{\text {nd }}$ Ed., Dar Memphis for Printing, Cairo, 142 pp.

El-Hifny, I.M.M.; Ramadan, M.E.; El-Oksh, I.I. and Soliman, M.M. (2008). Effect of some cultural practices on cauliflower tolerance to salinity under Ras Suder conditions. J. Biol. Chem. \& Environ. Sci., 3(1):899- 913.

El-Sayed, H.E.A. (2014). Impact of magnetic water irrigation to improve the growth, chemical composition and yield production of broad bean (Vicia faba, L.) plant. Amer. J. Experiment. Agric., 4(4):476-496.

Euliss, K.W. and Carmichael, J.S. (2004). The effects of selenium accumulation in hydropnically grown canola (Brassica napus, L.). J. Young Investigators, 10(1):1-10.

Germ, M. and Stibilj, V. (2007). Selenium and plants. Acta Agric. Slovenica, 89(1):65-71.

Gunes, A.A.; Alpaslan, M. and Cikili, Y. (1999). Effect of salinity on phosphorus induced zinc deficiency in pepper plants. Tr. J. Agric. \& Forest., 23:459-464.

Hajiboland, R. and Keivanfar, N. (2012). Selenium supplementation stimulates vegetative and reproductive growth in canola plants. Acta Agric. Slovenica, 99(1):13-19.

Hawrylak-Nowak, B. (2008). Effect of selenium on selected macronutrients in maize plants. J. Elementology, 13(4):513-519.

Hozyan, M. and Abdul-Qados, Amira M.S. (2010). Irrigation with magnetized water enhances growth, chemical constituents and yield of chickpea (Cicer arietinum, L.). Agric. and Biol. J. of N. Amer., 1(4):671-676.

Jackson, M.L. (1973). Soil Chemical Analysis. Prentice Hall of India Private Ltd M-97, Delhi, India, 498 pp.
Jou, Y.; Chiang, C.; Jouh, G. and Yen, H. (2006). Functional characterization of ice plant, an AAA-type ATP-ase associated with the endoplasmic reticulum-Golgi network; and its role in adaptation to salt stress. Plant Physiol., 141(1):135-146.

Kaklewski, K.; Nowak, J. and Ligocki, M. (2008). Effects of selenium content in green parts of plants on the amount of ATP and ascorbate-glutathione cycle enzyme activity at various growth stages of wheat and oil seed rape. J. Plant. Physical., 165(10):1011-1022.

Lehotai, N.; Peto, A.; Erdei, L. and Kolbert, Z. (2011). The effect of selenium on development and nitric oxide levels in Arabidopsis thaliana seedlings. Acta Biologica Szegediensis, 55(1):105-107.

Luatanab, F.S. and Olsen, S.R. (1965). Test of an ascorbic acid method for determining phosphorus in water and $\mathrm{NaHCO}_{3}$ extracts from soil. Soil Sci. Soc. Amer. Proc., 29:677-678.

Lyons, G.H.; Gene, Y.; Soole, K.; Stangoulis, J.C.R.; Liu, F. and Graham, D. (2009). Selenium increases seed production in Brassica. Plant Soil, 318:73-80.

Mostafazadeh, B.; Khoshravesh, M.; Mousavi, S.F. and Kiani, A.R. (2012). Effects of magnetized water on soil chemical components underneath trickle irrigation. Amer. J. Irrig. Drain. Eng., 138(12):1075-1081.

Pregl, F. (1945). Quantitative Organic Micro-Analysis, $4^{\text {th }}$ Ed., J. and A. Churchill Ltd., London, p: 203-209.

Saffaryazdi, A.; Ahouti, M.; Ganjeali, A. and Bayat, H. (2012). Impact of selenium supplementation on growth and $\mathrm{Se}$ accumulation in spinach (Spinacia oleracea, L.) plants. Not. Sci. Biol., 4(4):95-100.

Saric, M.; Kastrori, R.; Curic, R.; Cupina, T. and Geric, I. (1976). Chlorophyll Determination. Univ. U Noven Sadu 


\section{Gehan H. Abdel-Fattah}

Parktikum is Fiziologize Biljaka, Beogard, Haucna, Anjiga, 215 pp.

SAS Institute Program (1994). SAS/STAT User's Guide: Statistics, Vers. 6.04, $4^{\text {th }}$ Ed., SAS Institute. Inc., Cary, N. C., USA.

Shehata, S.A.; Ahmed, Y.A.; Emam, Y.T. some organic and inorganic fertilizers on vegetative growth, yield and yield components of cucumber plants. Res. J. of Agric. \& Bio. Sci., 8(2):108-114.

Tester, M. and Davenport, R. (2003). $\mathrm{Na}^{+}$ tolerance and $\mathrm{Na}^{+}$transport in higher plants. Ann. Bot., 91:503 - 527.

and Azoz, M.A. (2012). Influence of

\section{دور الحديد الممغنط وسيلينات الصوديوم في خفض أضرار ملوحة التربة وتاثير هما على نمو وجودة شتلات الجكرندا \\ جيهان حسن عبد الفتاح \\ قسم بحوث الحدائق النباتية، معهد بحوث البساتين، مركز البحوث الزر اعية، الجيزة، مصر.}

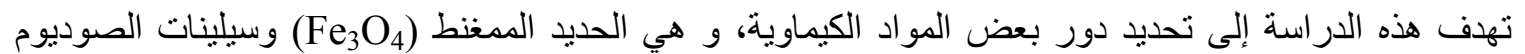

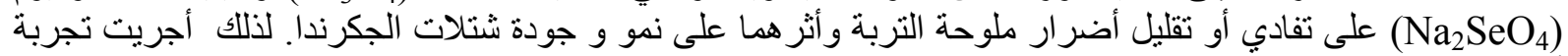

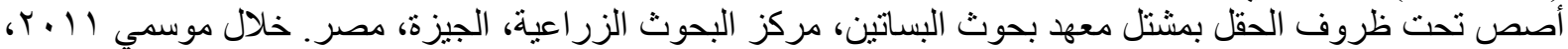

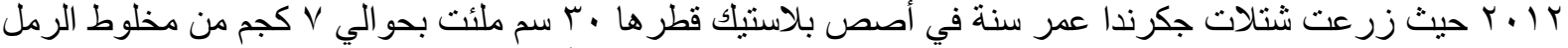

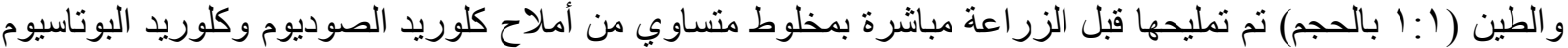

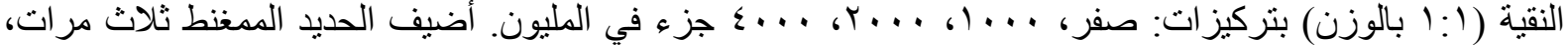

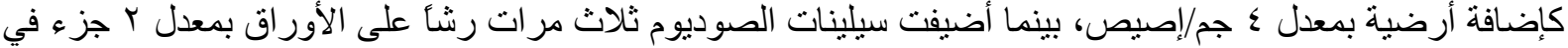

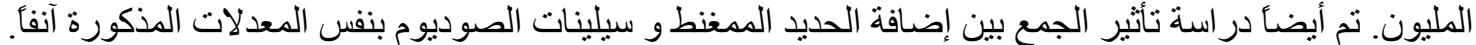

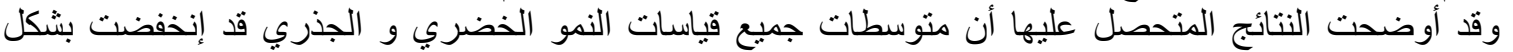

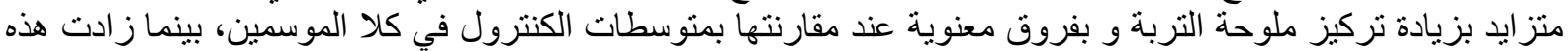

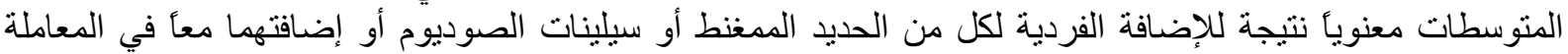

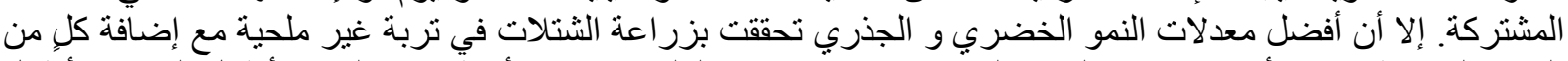

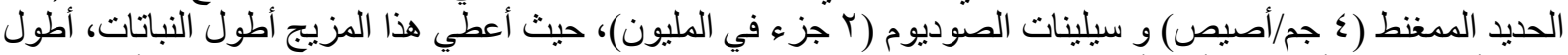

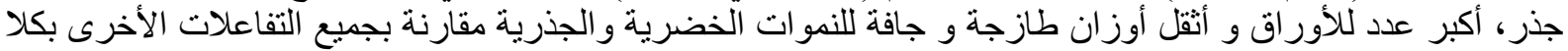

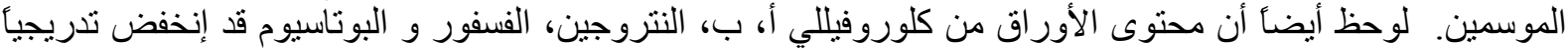

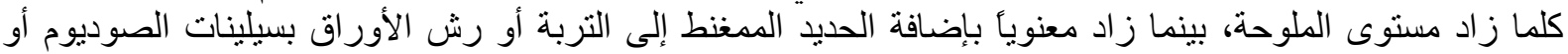

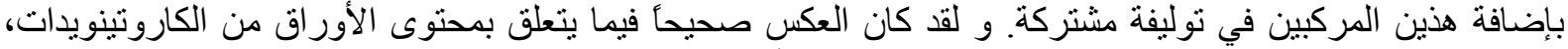

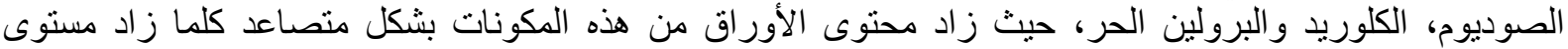

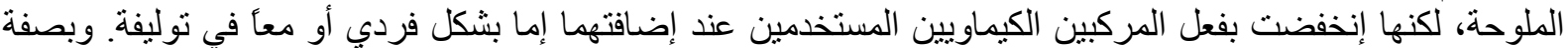

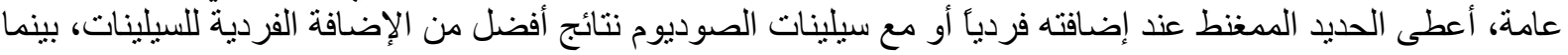

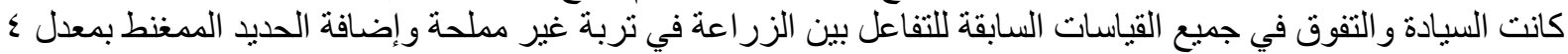

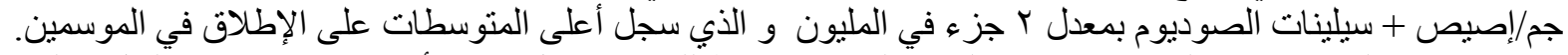

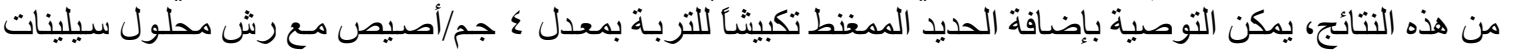

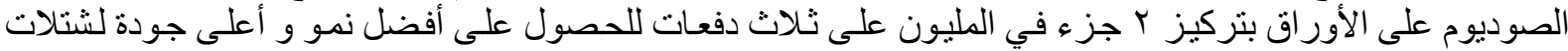
الجكرندا عند زر اعتها في تربة ملحية أو غير ملحية. 